\title{
MOBILE SERVICE USAGE BEHAVIOR IN KOREA: AN EMPIRICAL STUDY ON CONSUMER ACCEPTANCE OF INNOVATIVE TECHNOLOGIES
}

\author{
Yeong-Wha Sawng ${ }^{1}$, Seung-Ho Kim ${ }^{2}$, Jungmann Lee ${ }^{3}$, Young Sam $\mathrm{Oh}^{4}$ \\ ${ }^{1}$ Electronics and Telecommunications Research Institute, Yuseong-gu, Daejon, Korea \\ ${ }^{2}$ Korea Institute of Industrial Evaluation, Daegu, Korea \\ ${ }^{3}$ Hoseo University, Anseodong 268 Cheonan city, Chungnam Province, Korea \\ ${ }^{4}$ Inha University, Incheon, Korea \\ E-mails: ${ }^{1}$ ywsawng@gmail.com; ${ }^{2}$ kshuri@gmail.com; \\ ${ }^{3}$ mann@hoseo.edu (correspondingauthor); ${ }^{4} y$ so@inha.edu
}

Received 02 November 2009; accepted 11 January 2011

\begin{abstract}
Whilst mobile services have grown to a sizeable market in recent years, and leaps and bounds have been made in related technology, consumers' usage behavior with regard to these services has received little attention from researchers. Studies on related topics are few and scarce, if compared, for example, to studies on information systems or web services. The main purpose of this study is to investigate consumers' usage behavior in mobile services to provide pointers for future development of this field. Specifically, this study attempts to identify variables influencing the use of mobile service consumers. We developed an information technology acceptance model to determine usage characteristics and usage trends in mobile services and predict consumers' usage behavior based on patterns discerned from these characteristics and trends. Information technology acceptance models are a useful tool for understanding the behavior of consumers of services such as mobile services, combining aspects of a technology and service good, from the perspective of behavioral science. This study, comprehensively concerned with mobile service marketing-related issues, considers both factors influencing consumers' usage behavior and also technical aspects of services. Factors influencing the behavior of mobile service consumers are investigated empirically, by examining them in a real-world context. The expected outcomes of this study are as follows: First, it will predict consumers' usage behavior with regard to mobile services based on usage characteristics at the level of task management, and discern identifiable and recurring patterns. Second, it will awaken providers to the importance of technical and functional performance and a clear understanding of consumers' needs for the success of marketing mobile services.
\end{abstract}

Keywords: mobile service, consumer usability, consumer acceptance, consumer intention.

Reference to this paper should be made as follows: Sawng, Y.-W.; Kim, S.-H.; Lee, J.; Oh, Y. S. 2011. Mobile service usage behavior in Korea: an empirical study on consumer acceptance of innovative technologies, Technological and Economic Development of Economy 17(1): 151-173.

JEL Classification: C52, C83, M31. 


\section{Introduction}

The Korean mobile service industry, after starting out with services targeting 1st-gneration analog cellular devices, has since then undergone rapid expansion and is today supplying to $3^{\text {rd }}$-generation device markets such as WCDMA and HSDPA. As a result of technological progress and improvement in income, consumers' needs in technology products and services have been fast evolving in recent years, and this has, in turn, caused the market environment to change rapidly. In December 2007, the Korean mobile service market passed the 45 million subscriber mark, and its $3 \mathrm{G}$ segment reached over 10 million subscribers. $3 \mathrm{G}$ mobile services currently in offer in Korea are considered to have largely surpassed $2 \mathrm{G}$ services in terms of network efficiency and service capacity, outperforming them by more than $30 \%$ in both areas. $3 \mathrm{G}$ services are also optimally adapted for data communications. With $3 \mathrm{G}$ services, mobile consumers have not only a seamless access to all traditional internet content, such as movies and music, but also can use data-heavy applications such as video phone. Meanwhile, the voice-centered mobile service market is quickly reaching the point of saturation with the potential for further increasing revenue being all but exhausted. $3 \mathrm{G}$ services, as a new alternative more adapted for transfer of data and multimedia content, are expected to offer new revenue opportunities for the mobile market. In spite of this exponential growth of mobile services and leaps and bounds made in related technology, few attempts have been thus far made to understand consumers' usage behavior with regard to these services. The existing literature on this topic is scanty, especially if compared to the wealth of studies dealing with information systems and web services.

The main purpose of this study is to investigate consumers' usage behavior in mobile services to provide pointers for future development of this field. Specifically, this study attempts to identify variables influencing the use of mobile service consumers.

We developed an information technology acceptance model to determine usage characteristics and usage trends in mobile services and predict consumers' usage behavior based on patterns discerned from these characteristics and trends. Information technology acceptance models are a useful tool for understanding the behavior of consumers of services such as mobile services, combining aspects of a technology and service good, from the perspective of behavioral science. This study, comprehensively concerned with mobile service marketing-related issues, considers both factors influencing consumers' usage behavior and also technical aspects of services. Factors influencing the behavior of mobile service consumers are investigated empirically, by examining them in a real-world context.

The expected outcomes of this study are as follows: first, it will predict consumers' usage behavior with regard to mobile services based on usage characteristics at the level of task management, and discern identifiable and recurring patterns. Second, it will awaken providers to the importance of technical and functional performance and a clear understanding of consumers' needs for the success of marketing mobile services.

To achieve these research goals, we empirically estimate the relationship between characteristics related to the use and provision of mobile services and factors influencing consumers' satisfaction such as perceived benefit and risk. Four constructs related to usage characteristics were selected as measured variables; namely, perceived usefulness, perceived ease of use, perceived cost and perceived network effects. Perceived benefit variables include 
economic benefits, service-specific benefits and social benefits, and perceived risk variables, service risk and cost risk. The rest of this paper is organized as follows: In Section II, we review existing literature on the process of individual's acceptance of information technology, examining more particularly theoretical models such as the diffusion of innovations theory, information technology acceptance models, technology task fit model and perceived risk theories. In Section III, we describe the research model developed for this study, drawing on the existing literature, and formulate hypotheses on the relationship between the variables. Finally, in Section IV, the paths of influence between the variables are empirically estimated using a structural equation model.

\section{Theoretical Background}

\subsection{Literature on Information Technology Acceptance}

\subsubsection{Diffusion of Innovations Theory}

Rogers (1995) distinguishes five stages in the process by which an individual comes to adopt an innovation: knowledge, persuasion, decision, implementation, and confirmation (see Fig. 1). The stage of knowledge corresponds to the initial phase in which an individual is first exposed to an innovation and develops an understanding about how this innovation works. The process by which an individual develops knowledge related to an innovation is largely influenced by his/her personal taste, needs and desires, and past experiences, as well as the values and norms of the social systems (Weiber 1992, 1994). The knowledge developed during this stage serves the potential adopter of the innovation as the basis to form his/her opinion about the innovation in question. In other words, during the stage of persuasion, the potential adopter forms either a favorable or unfavorable attitude toward the innovation, based on the knowledge he/she has gained from the initial knowledge stage. While the individual's mental activity during the knowledge stage is mostly cognitive in nature, during the persuasion stage, it is predominantly affective. As a general rule, the easier it is to observe the results of an innovation and to communicate them to others, the higher the probability that the potential adopter will actually choose this innovation (Rogers 1995). This decision whether to adopt or reject the innovation is made during the third stage, and the attitude developed during the persuasion stage provides the basis for decision-making. According to Rogers (1995), most individuals are willing to try out an innovation before forming an opinion. The intention to adopt an innovation is usually dependent on whether or not the potential adopter sees relative benefits or advantages associated with the adoption of the innovation. It is during the fourth stage, in other words, the stage of implementation that the final decision is made on whether to adopt or reject the innovation. The implementation, therefore, occurs when an individual reaches the final decision to use the innovation. During the implementation stage, most individuals keep searching information about the innovation, as some degree of uncertainty on the potential consequences of using this innovation still lingers. Finally, during the stage of confirmation, an individual, based on the level of satisfaction he/she experiences with regard to the results of using the innovation, considers whether or not to continue to use the innovation. A satisfied innovation adopter would typically choose the same product at the next purchase occasion (Borchert et al. 2004). 


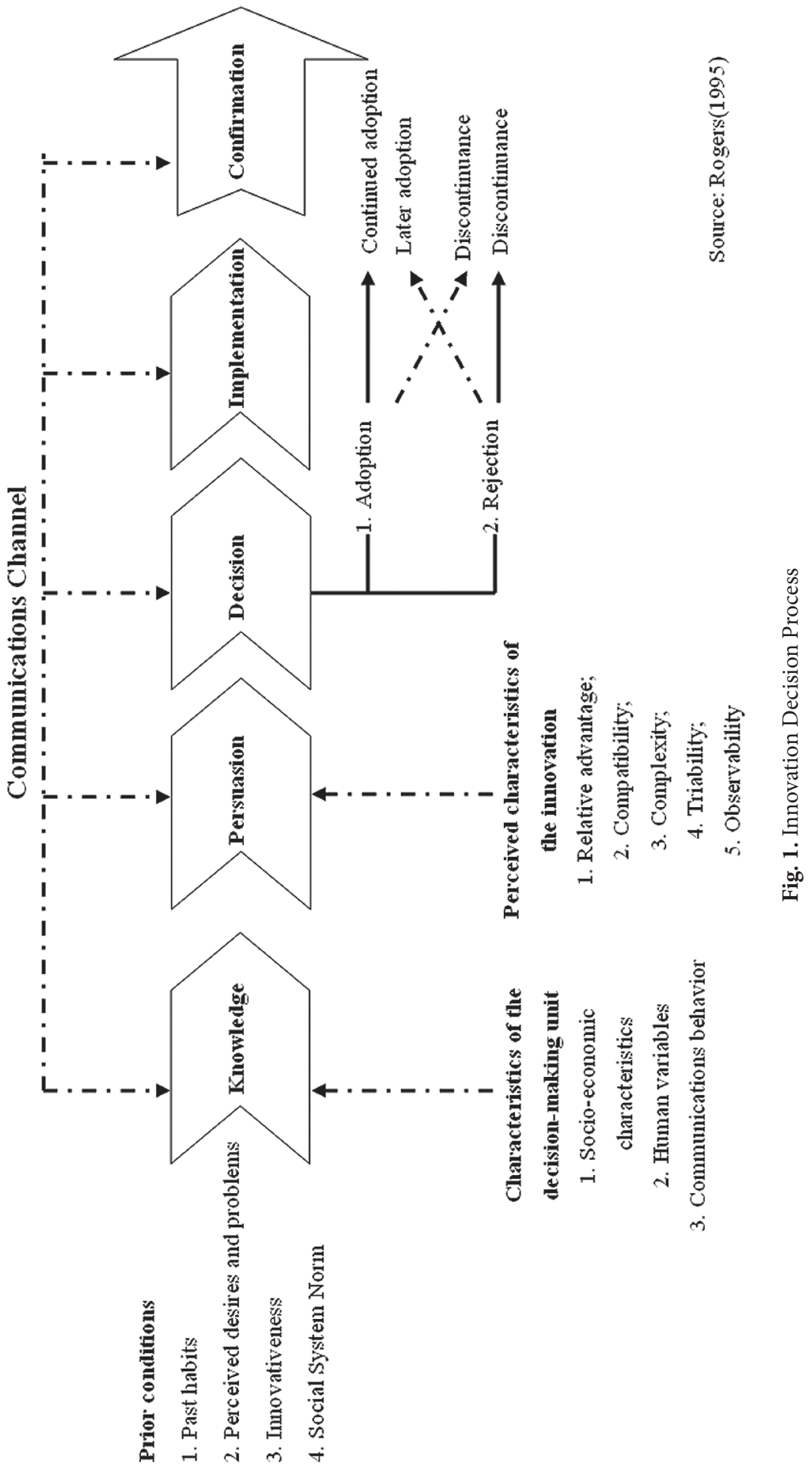


The first three of the five stages in the innovation decision process are each related to 'belief,' 'attitude' and 'intention' in the technology acceptance model (TAM), and provide the basis for combining the diffusion of innovations theory with TAM. Benbasat and Dexter (1992) developed a method for measuring constructs believed to influence the adoption and acceptance of innovations, based on the diffusion of innovations theory and related literature. Using this method, he measured the extent to which these factors actually influence individuals' use of information technology. Meanwhile, 'perceived risk', a concept proposed by Rogers in the context of potential innovation adopters' assessment of the relative quality of a product, has been reported to be one of the important reasons why customers are reticent about e-commerce (Schmalen and Pechtl 1996). Borchert et al. (2004) elaborated a new model to measure the effects of various factors deemed to influence buyer behavior on the frequency and value of purchase, drawing on the diffusion of innovations theory and marketing literature on related topics. His analysis found that four factors, including internet usage, search capacity, confidence in the seller and confidence in the security of transactions over the internet had a positive influence on the frequency and value of purchase. Regarding mobile services specifically, consumers' knowledge and experience of the internet are believed to influence their perceived ease of use (Hoffman et al. 1995). Prior experience proves to be crucial in the acceptance of innovations, insofar as an innovation which appears too new or unfamiliar or whose use requires extensive changes in consumers' past habits tends to increase the barrier to acceptance. The level of acceptance is generally lower with innovations based on an entirely new body of knowledge, in other words, innovations with which consumers have little prior experience. This is also the reason why with innovative products or services new to the market, those consumers who are able to understand their innovative characteristics and assess them appropriately, tend to accept them earlier than others (Gerpott 1999). In addition to consumers' knowledge of computer and the internet, the perceived ease of use with regard to a mobile service is often influenced also by the familiarity of the software and ease of its installation (Döring 2002). Perceived familiarity, therefore, is an essential requirement for the market success of a new technology or service (Hoffman et al. 1995). In other words, the mode of network access should be familiar to mobile service consumers, the interface, easy and convenient to use and search functions more powerful (Harms 2002).

In this study, to determine innovation acceptance characteristics of mobile service consumers, we begin by examining possible reasons why a consumer accepts or rejects a new information technology. This choice is based on the likelihood that the benefits consumers expect from an innovation play a determining role in their acceptance of it (Reichwald 1982). The knowledge of why consumers accept or reject a mobile service, furthermore, can assist service providers in designing marketing strategies which closely takes into consideration innovation acceptance characteristics of consumers. Needless to say, achieving rapid acceptance by consumers is vital for the market prospects of a new mobile commerce service (Kollman 1998, 2004).

\subsubsection{Technology Acceptance Model}

The TAM (Technology Acceptance Model), developed by Davis et al. (1989) (see Fig. 2), is a model widely used to explain and predict consumer behavior with regard to the acceptance of information technology. 


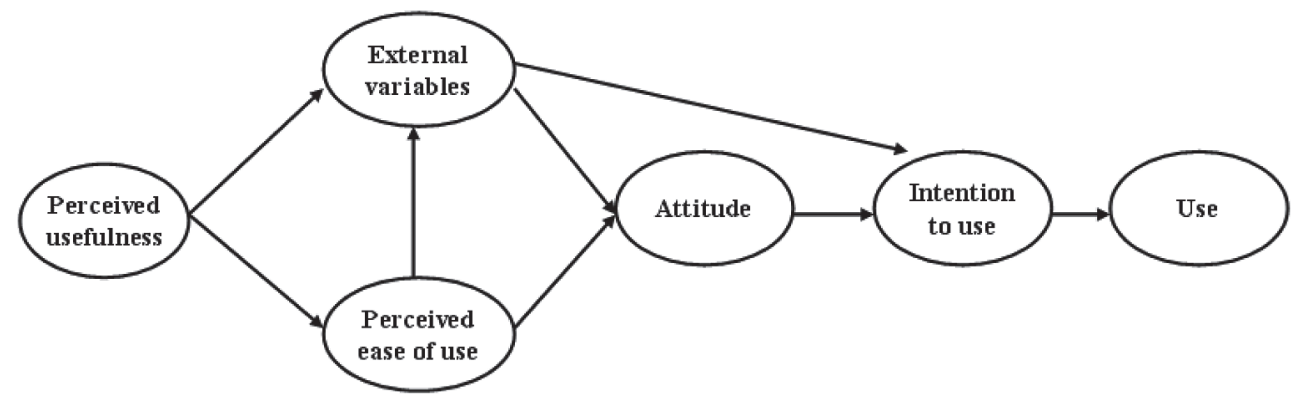

Fig. 2. Technology Acceptance Model Source: Davis et al. (1989)

An extension of Fishbein and Ajzen's (1975) theory of reasoned action (TRA), the TAM explains how consumers come to accept and use a technology. In his original study, Davis (1989) sketched out basic relationships between cognitive and affective variables influencing the acceptance behavior of a technology consumer, using the conceptual tools provided by the theory of reasoned action. In the TAM, acceptance behavior is determined by two beliefrelated factors, 'perceived usefulness' and 'perceived ease of use,' and whether an information technology would be ultimately accepted by its potential consumers is predicted using the belief - attitude- intention - behavior sequence proposed in the theory of reasoned action. Perceived usefulness and perceived ease of use, as the two key belief factors shaping the attitude, intention and behavior of a technology consumer, are believed to lead to the acceptance of a new information technology (Lederer et al. 2000). Notwithstanding, in some cases, the influence of perceived ease of use on the acceptance of a technology can be negligible or difficult to prove, and this phenomenon is explained by the fact that the relative importance of influence factors for technology acceptance varies depending on the type and characteristics of the task for which a new technology is used (Neudorfer 2004). Previous studies found that perceived ease of use had a greater influence on the acceptance behavior of technology consumers, than usage characteristics related to using or purchasing high-quality information services or products, if and when a technology is employed for its originally-intended purposes, in other words, to use an information system (ex. searching educational materials, etc.) (Gefen and Staub 2000). Accordingly, in this attempt to measure the impacts of various factors influencing the acceptance behavior of mobile service consumers, our primary focus is placed on the consumer perception of security and reliability.

\subsubsection{Task Technology Fit Model}

The task technology fit model (TTFM) is a tool to assess the extent to which an information system supports the tasks carried out by potential consumers. This model, developed by Goodhue and Thompson (1995), has been popularly employed in the context of research to gauge the satisfaction and attitude of consumers with regard to information systems, as well as MIS research. The task technology fit model is considered a pertinent tool for evaluating the quality of an information system and predicting how much an information system would be 
actually used by potential consumers. Although this model has been thus far used mostly as a secondary tool, at least within the context of acceptance research, given its effectiveness in evaluating service providers' capability to address consumers' needs at the level of information systems, it could very well be used as an alternative explanatory model for acceptance behavior. This is because the acceptance of a technology is susceptible to general factors such as the fit between information systems, tasks, technologies and individual consumers (Goodhue and Thompson 1995). Dishaw and Strong (1998), in their investigation of the TTFM, stated that one of the model's postulates is that software will be used if, and only if, the functions provided by it support the tasks performed by the consumer. In other words, a consumer with the habit of rational thinking and prior experience using information systems is bound to choose a tool that enables him/her to successfully perform a task, delivering maximum effectiveness at a minimal cost. The influence variables in the TTFM, including technology, task and fit, are defined as follows (Amberg et al. 2003): first, technology is regarded in the TTFM as a tool supporting individual consumers' activities (Goodhue and Thompson 1995). Technology, in other words, is a support service assisting both the computer system and the consumer with the performance of his/her primary tasks. The term 'technology,' as used in the TTFM, has a broad and rather general meaning. This is because technology not only designates concrete systems, but also refers to all influences that information systems may have on potential consumers and their activities. Second, tasks are understood as all activities through which an input is converted into an output. One thing to be noted in regards to tasks in the context of TTF is that with an interesting task, the consumer relies more extensively on information technology. Individuals are agents who use technologies that can assist them with the performance of their respective tasks, and individual characteristics (amount of training and experience with using computer and motivation, etc.) influence how easily a consumer learns to use a new technology. Third, 'fit,' the pivotal concept in the TTFM, is a variable closely related to the consumer's experience of satisfaction.

To enable quantitative measurement, Goodhue and Thompson distinguished twelve dimensions of task-technology fit: accessibility, assistance, ease of use, system reliability, data accuracy, compatibility, currency, presentation, confusion, the level of detail, meaning and locatability. A higher level of task-technology fit increases the consumers' expectations on the results and allows him/her to perform a higher-level task as well (Goodhue and Thompson 1995). In this study, we assume that the three influencing factors in the TTFM are at work also in the process of acceptance of mobile services, and will use this model to evaluate the fit between a mobile service and its potential consumers (Amberg et al. 2003).

\subsubsection{Theory of Perceived Risk}

The concept of perceived risk was first proposed by Bauer (1960). Bauer stated that the consequences of a choice made by a consumer can be unpredictable and some of these unforeseen consequences can be undesirable. Perceived risks refer to the potential risks of a purchase decision as perceived by consumers. Perceived risks, meanwhile, should be distinguished from objective or statistical risks, insofar as consumers only respond to subjectively-perceived risks, and such subjective risks perceived by a consumer may or may not prove real. Cox (1967) 
explained perceived risk by two factors: the perceived extent of loss that may be incurred from an unwanted outcome of a purchase decision and the perceived amount of security that the purchase would not lead to an unexpected outcome. These two concepts provide a basis for risk reduction strategies to decrease the possible loss and increase the level of security to avoid undesirable consequences (Neudorfer 2004). As for Bettman (1973), he further elaborated the concept of perceived risk by distinguishing two types: inherent risk and handled risk. Inherent risk is the latent risk a product class holds for a consumer, in other words, the innate degree of conflict a product class can arouse in a consumer. Handled risk, on the other hand, represents the conflict potential which still exists when choosing a brand from a product class at the moment of the purchase decision, and may, therefore, be described as the 'perceived residual risk.' Using the distinction between these two components, Bettman measures the risk-reduction behavior of consumers (Neudorfer 2004). Meanwhile, Cox (1967) states that the realization that the goals of purchase may not be reached arouses anxiety in consumers, and the perception of risk stems from the consumer's uncertainty about his/her own goals of purchase, whether a product corresponds to the goals of purchase (if the goals are known), or whether he/she will be satisfied with the consequences of the purchase. In other words, perceived risks are negative consequences perceived by a consumer in relation to a purchase decision, when he or she is unsure about the goals of his/her own purchase, which product or model corresponds best to the goals of purchase or whether he/she will be satisfied with a product, after the product is bought. Cunningham (1967) classified perceived risks in a purchase decision into six types: financial loss, physical loss, psychological loss, time loss, social risk and performance risk. Perceived risk in a purchase decision is determined by negative purchase consequences and insecurity (see Fig. 3). Insecurity is closely related to the possibility envisioned by a consumer that the goals of his/her purchase may not be achieved, and the consequences of a purchase include the consequences of a purchase decision. The theory of perceived risk, therefore, maintains that a behavioral pattern can be extrapolated from how a consumer handles the risk they perceive in a purchase decision. According to their attitude toward risk taking, in other words, their level of willingness to accept a risk, consumers can be classified into three groups: risk-friendly, risk-averse and risk-neutral consumers (Neudorfer 2004). In order to measure perceived risk with a reasonable degree of accuracy, using constructs such as negative purchase consequences and insecurity, these

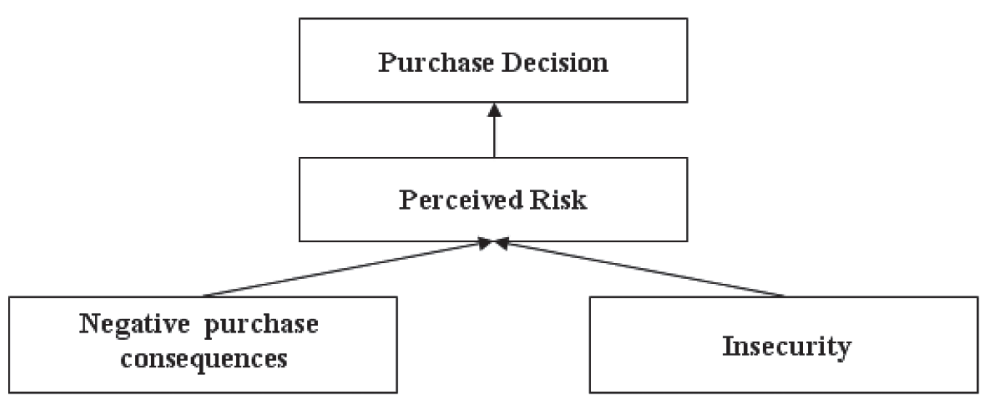

Fig. 3. Factors Influencing Perceived Risk 
constructs must be appropriately adjusted. For these constructs to be used in the analysis of consumer behavior in advanced and complicated technology products such as mobile services, these perceived risk factors need to be clearly defined (Weiber 1994).

\subsection{Concept of Mobile Service and Literature Review}

Mobile commerce services allow their consumers to exchange values and conduct business transactions over wireless networks, using portable devices. It is a superior alternative to ecommerce in that transactions can be conducted at any time and from anywhere (Villanen et al. 2004). Although similar to e-commerce insofar it uses the internet, mobile commerce is distinct from the latter in terms of enabling technologies and business models. As devices used for accessing wireless internet are portable devices limited in data storage capacity and interface functionality, the medium emphasizes network-centered mobility and is evolving into a platform which is more personalized than mobile internet with service providers taking up an active role in resolving temporal and spatial constraints experienced by consumers (Turowski and Pousttch 2004). On the consumer side, mobile internet is also distinct from fixed internet access, as it does not offer extended hours of search and free access to information. The duration of connection is shorter with mobile internet, and access to information and services is on a pay-for-use basis (Buse 2002). Neudorfer (2004), in his study investigating factors influencing the acceptance of mobile services, found that expected benefits had a positive influence on the probability of adoption. Meanwhile, his investigation found that perceived risk (service risk and cost risk) had no significant influence on consumers' acceptance of mobile services. Amberg et al. (2003) measured customers' satisfaction with mobile services, before and after the actual experience of the services, and found that usefulness, ease-of-use, cost and mobility were factors effectively influencing consumers' attitude toward a mobile service both during and after the use. Pleasure experienced using text services and their perceived usefulness and usability have been also reported to have an influence on the level of consumer satisfaction with mobile services (Doring 2002). Lehner (2003), in his study on the characteristics of mobile content interface, content services and mobile internet usage, found that convenience and efficiency were the two most important factors influencing the acceptance of mobile services. According to his results, at the level of content interface, structural simplicity and ease of search effectively influenced the acceptance behavior of mobile service consumers. Meanwhile, he measured variables including accuracy, timeliness, personalization, specialization, locatability and simplicity to characterize mobile service providers. Bullinger and Schreiner (2003) investigated mobile internet users' behavioral intention using the TAM and found that the quality of the system and information influenced perceived pleasure, ease of use and usefulness.

\section{Research Model and Hypotheses}

\subsection{Research Model}

Drawing on theoretical and empirical literature on consumer behavior and the acceptance of information technology, we created a conceptual model to explain consumers' usage 
behavior in mobile services. Based on constructs influencing technology acceptance from previous studies and relationships that are reported to exist between them, we investigated how the various usage characteristics in mobile services influence each other (see Table 1).

Table 1. Comparison with Previous Research Models

\begin{tabular}{lll}
\hline Previous Research Model & \multicolumn{1}{c}{ Research Objective } & \multicolumn{1}{c}{ Weaknesses } \\
\hline Adoption theory & $\begin{array}{l}\text { Explain the diffusion of innovations } \\
\text { at the consumer level }\end{array}$ & $\begin{array}{l}\text { No quantification or prioritization } \\
\text { of product attributes }\end{array}$ \\
\hline Diffusion Theory & $\begin{array}{l}\text { Explain the diffusion of innovations } \\
\text { at the aggregate level }\end{array}$ & $\begin{array}{l}\text { No rational explanation provided } \\
\text { as to the success/ failure of diffusion }\end{array}$ \\
\hline $\begin{array}{l}\text { Model for the explanation } \\
\text { of consumers' acceptance }\end{array}$ & $\begin{array}{l}\text { Explain consumers' reasons for using/ } \\
\text { or not using a technology product }\end{array}$ & Overall ill-adapted to m-services \\
\hline Theory of perceived risk & $\begin{array}{l}\text { Explain acceptance through perceived } \\
\text { risk }\end{array}$ & $\begin{array}{l}\text { Only pertinent to characterization } \\
\text { of risks }\end{array}$ \\
\hline
\end{tabular}

The above attempts at explaining the mechanism of diffusion of innovations are variously limited by their failure to clearly account for the role of perceived risk or product attributes or provide rational explanations to consumers' acceptance behavior. Further, the set of factors influencing consumers' acceptance of innovations considered is either outdated or incomplete, as most investigated cases of failed innovations date from some decades ago. The explanatory capacity of the theory of perceived risk is also limited, as it falls short of explaining the extent to which various risk factors influence consumers' acceptance behavior or whether there are certain acceptance factors which counter the effect of any of the risk factors.

Expanding on the existing literature on consumer behavior, we investigate consumers' usage behavior in mobile services by examining the interaction between the different factors of influence delineated in the research model in Fig. 4 . We begin by constructing a theo-

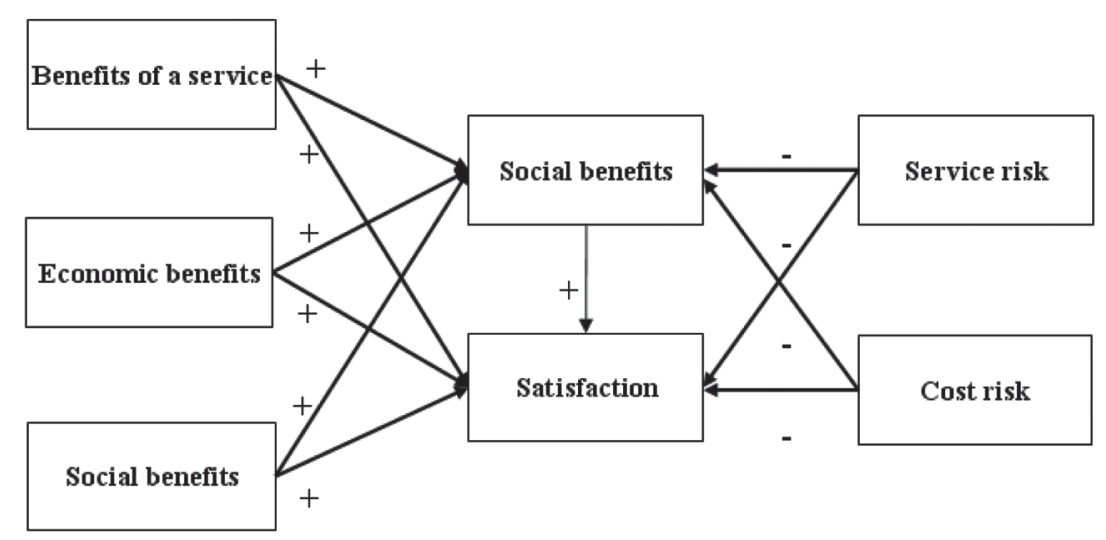

Fig. 4. Research Model on Mobile Service Acceptance Characteristics 
retical model for explaining consumers' usage behavior in mobile services and formulating hypotheses about various influence paths. Next, we select variables for each of the constructs and set up hypotheses about relationships of influence that may exist between them.

\subsection{Hypotheses}

\subsubsection{Relationship between Expected Benefits of Mobile Services and Acceptance Characteristics}

According to Neudorfer (2004), both an increase in expected benefits and the process of handling perceived risk can heighten the adoption probability for a mobile service. Neudorfer measured expected benefits of mobile services, classifying dimensions in which benefits can be created and perceived into three categories: economic benefits, service-specific benefits and social benefits. Economic benefits, the most important benefits according to Neudorfer, include benefits arising from time-saving, as time saved may have economic consequences for the consumer, even if it cannot fully or appropriately translated in monetary terms. Hence, both money saved and times saved are considered economic dimensions in the context of the adoption of a mobile service. Service-specific benefits are potential benefits arising from the use of a mobile service application. Given the great diversity of mobile services offered, qualities related to mobility of mobile services (ubiquity, reachability, personalization, localizability, etc.) are classified into two broad dimensions, for simplicity's sake: time independence and place independence (Amberg et al. 2003). Social benefits, although a category of benefit difficult to quantify, are defined as benefits arising from social interaction through cyber communities. The mobile media allow people to reach beyond the traditional, geographically-limited social sphere to enter into contact with others in remote locations.

Inter-human benefits gained from communicating with people of similar interest through email would be a good example of social benefits. Social benefits are broadly defined as including fun, enjoyment and entertainment associated with social interaction through mobile media. Based on the above benefit constructs, we set up the following three hypotheses concerning the relationship between perceived benefits and the acceptance of a mobile service:

H 1-1: Service-specific benefits have a positive influence on the acceptance of an m-service and the degree of satisfaction felt by consumers.

$H$ 1-2: Social benefits have a positive influence on the acceptance of an $m$-service and the degree of satisfaction felt by consumers.

H 1-3: Economic benefits have a positive influence on the acceptance of an $m$-service and the degree of satisfaction felt by consumers.

\subsubsection{Relationship between Perceived Risk Factors and Acceptance Characteristics}

Perceived risk is a component of a consumer's purchase behavior having to do with the prospect of reaching the goals of a purchase, which plays a determining role in the purchase decision. In this study, following the existing literature, we distinguished two types of perceived risk: service risk and cost risk. Service risk is related to the innovation characteristics 
of a particular technology, and the technology, in turn, affects the outcome of a purchase. Potential benefits of an innovative service and technology are important criteria of consideration for consumers, in a purchase decision. Consumers who have negative perceptions of a technology's innovation characteristics tend also to perceive the outcome of their purchase as risky. Negative perceptions of innovation characteristics would lead consumers to form negative opinions about the quality of components of a mobile service, or the capacity or reliability of the service provider. Consumers' negative perceptions about the outcome of their purchase means the low level of acceptance for the technology in question, as they indicate that their perceptions of integration capacity and ease of use are also negative. Hence, service risk may be defined as a risk related to insecurity. Cost risk has to do with market and provider-related purchase consequences, and concerns primarily the change in costs and cost assessment. Negative market-related purchase consequences may be a sharp decrease in the price of the service or a better alternative becoming available after the purchase. Negative provider-related purchase consequences include inadequate installation support, the absence of free repair service, a long waiting time for service and provider-supplied information proving inaccurate; all of which may result in additional costs for consumers. The perceived risk of an innovation and the assessment of this risk have a direct influence on consumers' purchase behavior. Acceptance characteristics and consumers' purchase behavior with regard to an innovation are determined by the process of adoption. As the adoption process for an information technology is rather long and complicated, in order to use appropriate risk reduction strategies, one has to empirically measure the extent of influence of perceived risk. The acceptance characteristics of an innovation and consumers' purchase behavior toward it are also influenced to a degree by the amount of insecurity. It is, therefore, important to increase the security of transaction for consumers making a purchase decision, by providing more information regarding goal-related results (Neudorfer 2004). Concerning the relationship between the perceived risk and acceptance of a mobile service, we set up the following two hypotheses:

H 2-1: The service risk associated with an $m$-service has a negative influence on its acceptance and the degree of satisfaction felt by consumers.

H 2-2: The cost risk associated with an m-service has a negative influence on its acceptance and the degree of satisfaction felt by consumers.

\subsubsection{Relationship between Mobile Service Usage Characteristics and Satisfaction}

The characteristics of consumer acceptance are considered increasingly important in the evaluation of mobile services as well as in general research on this topic. This is because acceptance characteristics are highly meaningful, predictive indicators for consumers' usage behavior with mobile services (Amberg et al. 2003). To measure the characteristics of consumers' acceptance of mobile services, they developed a new model, called the "Compass Acceptance Model", expanding the original TAM model in which the acceptance of an innovative technology is determined by two generalized determinants, perceived usefulness 
and perceived ease of use. Their measurement of consumer acceptance characteristics in mobile services takes into consideration a variety of practical factors pertaining to common service situations and conditions. The traditional TAM model was reconstructed by adding new factors of influence, such as perceived costs and perceived network effects, which allowed them to measure more comprehensively the characteristics of consumers' acceptance of mobile services at different levels. Meanwhile, Silberer et al. (2002) included customers' satisfaction with mobile services applications as a measurement concept; something never previously done in studies comparing the TAM with other technology acceptance models (e.g. Goodhue, Egenhardt, Kollman). He measured this acceptance construct by examining hardware characteristics, the characteristics of transmissions costs and characteristics of mcommerce, as well as the characteristics of experience and correspondence to expectations.

Table 2. Factors Influencing Acceptance

\begin{tabular}{ll}
\hline \multicolumn{1}{c}{ Perceived product attributes } & \multicolumn{1}{c}{ Factors of influence } \\
\hline \multirow{3}{*}{ Perceived Usefulness } & - Value Added (e. g. Fun Factor, Information) \\
& - Emotions (e.g. Feeling of Independence) \\
& - Information Quality (e.g. Timeliness) \\
\hline Perceived Ease of Use & - Initial Operation (e.g. Registration, First Configuration) \\
& - Usability of Service (e.g. Intuitive Handing, Idle Time) \\
& - Usability of Terminal Equipment (e.g. Display, Keypad) \\
\hline \multirow{3}{*}{ Perceived costs } & - Money costs (e.g. Purchase costs, Basic Rates, Usage Costs) \\
& - Transparency (e.g. Tariff Models, Cost per Minute/Request/Bit) \\
& - Health Concerns (e.g. Dangerous Radiation) \\
Perceived Network Effects & - Network Coverage (e.g. Dissemination, Roaming) \\
& - Terminal Equipment (e.g. Design, Size, Colour) \\
& - Image (e.g. Service as Status Symbol, Group Affiliation) \\
\hline
\end{tabular}

Table 2 provides the list of constructs from existing literature, related to the characteristics of consumer acceptance with regard to mobile services. These constructs are appropriately redefined and reorganized to suit the purpose of this study. The constructs have the following relationships of influence between them: First, factors of influence related to perceived usefulness are factors having to do with value-added, emotional rewards and information quality. Second, perceived ease of use-related factors include experience at the initial operation, the usability of service and usability of terminal equipment. Third, perceived cost-related influence factors are monetary costs, transparency and health concerns. Finally, perceived network effects capture the general status of a mobile service and have an indirect influence on its acceptance. The network coverage of a service and the design, size and color of the monitor or display belong to this category of perceived product attributes. We set up one hypothesis about the relationship between consumer acceptance characteristics and satisfaction as follows:

$H$ 3: The characteristics of consumer acceptance of $m$-services have a positive influence on satisfaction. 


\section{Methodology and Empirical Analysis}

\subsection{Data Collection and Sample Characteristics}

A survey was conducted to collect the data needed to test the hypotheses advanced in this study. The target population of the survey was college students, as they represent the majority of mobile service consumers. The respondents were chosen among college students attending a Gyeonggi-area university and another university located in the Daejeon area. Working adults attending night schools made up a sizeable subgroup, whose age and occupation distributions are more diverse than the rest of the sample population. Thanks to its diversity, this subgroup plays the important role of reducing the influence of demographic variables. The survey was conducted on 250 respondents, and 197 responses were retained for analysis. The sample size is limited, but the extensive experience of members of this subgroup with various information technology media, including fixed internet and m-commerce, and their proficiency with wireless devices also speaks favorably about the appropriateness of this choice of target population to our purpose. The respondents break down as follows, by age group, education, gender, average monthly income and monthly average length of mobile service usage: people in their teens accounted for $31 \%$ of total respondents, people aged 20 to $29.66 \%$ and people aged 30 and older, $3 \%$. All respondents were enrolled in a college or university at the time of the survey, the sample population being college/university students. By gender, the number of women slightly exceeded that of men, representing $56 \%$ of total respondents. The average monthly income (allowance) of the sample ranged from 100.000 won to 400.000 won, and the distribution of the average monthly expenses also ranged between 100.000 won and 400.000 won. The average hours of mobile phone use per day, for calls, amounted to 2.7 hours for both men and women, and the monthly average cost, about 50.000 won. For services other than calls, the respondents used their mobile handsets over three times a day on average, to send text messages, look up information, play games and download mp3 music. These days, most cell phones plans include over 100 free text messages a month at no additional charges. There was no discernable difference between men and women in the usage of text messaging.

\subsection{Reliability and Validity Analysis}

To measure the extent to which known antecedents of the acceptance of mobile services actually influence consumers' acceptance behavior and their level of satisfaction, we employed a variety of analytical methods. First, the internal consistency of constructs was tested using Cronbach's Alpha, and any measurement items which proved unreliable were discarded. Second, a factor analysis was performed to test the construct validity of the measures. Third, a correlation analysis was performed on the remaining items to check for any correlations between the variables. Fourth and lastly, we performed a path analysis to estimate the research model by testing the measurement model and the structural model separately. 


\subsubsection{Reliability Analysis}

In this study, constructs drawn from previous research were given operational definitions, and measured through multiple-item scales and a 7-point Likert-type response format. Cronbach's Alpha coefficient was used for internal reliability analysis, and items of low reliability were excluded from the analysis. The reliability test performed on the variables retained for the analysis (see Table 3) after exclusion of these items resulted in a Cronbach's Alpha coefficient to 0.7 or higher for all scales; a level indicating a sufficient degree of reliability.

Table 3. Results of Reliability Test

\begin{tabular}{lllll}
\hline \multicolumn{2}{c}{ Constructs and Variables } & & Number of items & Cronbach alpha \\
\hline \multirow{3}{*}{$\begin{array}{l}\text { Service character } \\
\text { istics }\end{array}$} & Perceived ease of use & EOU & 4 & 0.752 \\
\cline { 2 - 5 } & Perceived costs & CST & 4 & 0.733 \\
\cline { 2 - 5 } & Perceived usefulness & USE & 3 & 0.736 \\
\cline { 2 - 5 } & Perceived network effects & NET & 3 & 0.730 \\
\hline \multirow{3}{*}{ Perceived benefits } & Service-specific benefits & SVC & 4 & 0.727 \\
\cline { 2 - 5 } & Social benefits & SCL & 3 & 0.737 \\
\cline { 2 - 5 } & Economic benefits & ECO & 2 & 0.742 \\
\hline \multirow{2}{*}{ Perceived risks } & Cost risk & SRK & 2 & 0.743 \\
\cline { 2 - 5 } & Service risk & CRK & 2 & 0.717 \\
\hline \multirow{2}{*}{ Service satisfaction } & & SAT & 3 & 0.741 \\
\hline
\end{tabular}

\subsubsection{Validity Analysis}

With regard to the validity of the items used in this study, the convergent validity of the instruments, indicative of the internal consistency between the items, can be measured by construct reliability. Discriminant validity, meanwhile, indicates to what extent the results of two measurements of the same attribute, using two different methods are related or coincide with each other (Campbell \& Fiske 1959). In this study, the discriminant validity of the measures was tested by factor analysis. To minimize information loss and reduce the number of factors for each variable to the smallest possible number, we used principal component analysis. The analysis was performed using Varimax rotation, an orthogonal rotation which maximizes the variance of the factor loadings. The orthogonally rotated factor matrix for the principal component analysis to test the construct validity of independent variables is displayed in Table 4 . The results of the factor analysis show that there were four factors that could be extracted at the 'service characteristics' level. Factor loadings from the principal component analysis were 0.5 or higher for all items, with communality estimates of 0.5 or higher. 
Table 4. Results of Factor Analysis on Mobile Service Characteristic Variables

\begin{tabular}{|c|c|c|c|c|c|c|c|}
\hline \multicolumn{4}{|c|}{ Variables } & \multirow{2}{*}{$\begin{array}{l}\text { Factor } 1 \\
0.833\end{array}$} & \multirow[t]{2}{*}{ Factor 2} & \multirow[t]{2}{*}{ Factor 3} & \multirow[t]{2}{*}{ Factor 4} \\
\hline \multirow{14}{*}{$\begin{array}{l}\text { Service } \\
\text { character- } \\
\text { istics }\end{array}$} & \multirow{4}{*}{$\begin{array}{l}\text { Perceived } \\
\text { ease of use }\end{array}$} & EOU1 & $\begin{array}{l}\text { Ease of information } \\
\text { access }\end{array}$ & & & & \\
\hline & & EOU2 & Information quality & 0.878 & & & \\
\hline & & EOU3 & $\begin{array}{l}\text { Quality of product infor- } \\
\text { mation }\end{array}$ & 0.798 & & & \\
\hline & & EOU4 & Pleasure of use & 0.788 & & & \\
\hline & \multirow{4}{*}{$\begin{array}{l}\text { Perceived } \\
\text { costs }\end{array}$} & CST1 & Saving on purchase cost & & 0.766 & & \\
\hline & & CST2 & $\begin{array}{l}\text { Saving on usage cost; } \\
\text { Perceived usefulness; } \\
\text { Perceived costs }\end{array}$ & & 0.782 & & \\
\hline & & CST3 & $\begin{array}{l}\text { Transparency of price } \\
\text { components }\end{array}$ & & 0.591 & & \\
\hline & & CST4 & Confidence in the seller & & 0.766 & & \\
\hline & \multirow{3}{*}{$\begin{array}{l}\text { Perceived } \\
\text { usefulness }\end{array}$} & USE1 & $\begin{array}{l}\text { Ease of initial setup and } \\
\text { use }\end{array}$ & & & 0.672 & \\
\hline & & USE2 & Usefulness of services & & & 0.721 & \\
\hline & & USE3 & Ease of handling & & & 0.780 & \\
\hline & \multirow{3}{*}{$\begin{array}{l}\text { Perceived } \\
\text { network } \\
\text { effects }\end{array}$} & NET1 & Usable anytime & & & & 0.773 \\
\hline & & NET2 & $\begin{array}{l}\text { anywhere; Diversity of } \\
\text { handset in design and } \\
\text { size }\end{array}$ & & & & 0.713 \\
\hline & & NET3 & $\begin{array}{l}\text { Availability of other } \\
\text { linked/partnered services }\end{array}$ & & & & 0.729 \\
\hline \multicolumn{2}{|c|}{ Eigen value } & & & 2.858 & 0.640 & 2.075 & 1.861 \\
\hline \multicolumn{2}{|c|}{$\%$ of variance } & & & 20.413 & 18.855 & 14.878 & 13.294 \\
\hline \multicolumn{4}{|c|}{ Cumulative $\%$ of variance } & 20.413 & 39.268 & 54.086 & 67.380 \\
\hline
\end{tabular}

The factor analysis on the perceived benefits and risks of mobile services was also performed. The results like 'service characteristics' level, although diverging from the initial expectations, indicate, nevertheless, a satisfactory level of discriminant validity between the independent variables.

\subsubsection{Confirmatory Factor Analysis}

Confirmatory factor analysis is used to test specific hypotheses for the extent to which they explain the interrelationships observed between the data. Hypotheses are formulated either based on prior knowledge or theoretical results, and restrictions may be imposed on the values of certain variables. Confirmatory factor analysis is performed either when exploratory research has been already completed, or when there exists a hypothetical but plausible instrument, to validate the assumptions (Kim 2001). In this study, we used the statistical 
package AMOS 4.0 for confirmatory factor analysis. The statistical package enables the analysis of complex causal relationships through covariance structural modeling.

To evaluate the validity of the constructs, we used model fit indices including $\mathrm{x}^{2}$ (the smaller, the better) including p-value (the optimal value is 0.5 or lower), RMR (Root Mean Square Residual; best if 0.05 or lower), GFI (Goodness-of-Fit; best if 0.9 or higher), AGFI (Adjusted Goodness-of-Fit; best if 0.90 or higher) and NFI (Normed Fit Index; best if 0.90 or higher). The results of the confirmatory factor analysis are listed in Table 5.

Table 5. Results of Confirmatory Factor Analysis

\begin{tabular}{|c|c|c|c|c|c|c|c|c|c|}
\hline \multicolumn{2}{|c|}{ Constructs } & $\begin{array}{l}\text { Num- } \\
\text { ber of } \\
\text { items }\end{array}$ & DF & $x^{2}$ & $\mathbf{p}$ & RNSR & GFI & AGFI & NFI \\
\hline \multirow{4}{*}{$\begin{array}{l}\text { Service char- } \\
\text { acteristics }\end{array}$} & $\begin{array}{l}\text { Perceived ease } \\
\text { of use }\end{array}$ & 4 & 2 & 15.3 & 0.00 & 0.033 & 0.96 & 0.82 & 0.96 \\
\hline & Perceived costs & 4 & 2 & 1.15 & 0.56 & 0.013 & 0.99 & 0.98 & 0.99 \\
\hline & $\begin{array}{l}\text { Perceived } \\
\text { usefulness }\end{array}$ & 3 & 5 & 8.1 & 0.15 & 0.033 & 0.98 & 0.95 & 0.96 \\
\hline & $\begin{array}{l}\text { Perceived net- } \\
\text { work effects }\end{array}$ & 3 & 0 & 0.0 & 0.0 & 0.0 & 1.0 & 1.0 & 1.0 \\
\hline \multirow{3}{*}{$\begin{array}{l}\text { Perceived } \\
\text { benefits }\end{array}$} & $\begin{array}{l}\text { Service-specific } \\
\text { benefits }\end{array}$ & 4 & 2 & 12.3 & 0.00 & 0.037 & 0.97 & 0.86 & 0.95 \\
\hline & Social benefits & 3 & 2 & 18.2 & 0.00 & 0.042 & 0.95 & 0.78 & 0.90 \\
\hline & $\begin{array}{l}\text { Economic } \\
\text { benefits }\end{array}$ & 3 & 0 & 0.0 & 1.00 & 0.0 & 1.0 & 1.0 & 1.0 \\
\hline \multirow{2}{*}{$\begin{array}{l}\text { Perceived } \\
\text { risks: Cost } \\
\text { risk, Service } \\
\text { risk }\end{array}$} & Service risk & 3 & 6 & 2.8 & 0.32 & 0.013 & 0.99 & 0.93 & 0.99 \\
\hline & $\begin{array}{l}\text { Service satis- } \\
\text { faction }\end{array}$ & 3 & 2 & 1.6 & 0.43 & 0.033 & 0.99 & 0.98 & 0.99 \\
\hline \multicolumn{2}{|c|}{ Service satisfaction } & 3 & 2 & 1.6 & 0.46 & 0.023 & 0.99 & 0.98 & 0.99 \\
\hline
\end{tabular}

The results of the confirmatory factor analysis proved to be generally satisfactory, although the $\mathrm{x}^{2}$ values for perceived ease of use and social benefits, and the $\mathrm{p}$-values for perceived costs, economic benefits and cost risk exceeded the cut-off values $(\mathrm{P}<0.5)$. However, the RMR values were close to 0 , and the GFI values, corresponding to the degree of the model fit, were above 0.9 for all constructs. The AGFI values of the constructs were mostly above 0.90 as well, and the values of the NFI, an index used for comparative purpose, are also satisfactory. The results, therefore, suggest that the measurement scales for each factor possesses construct validity (Hair et al. 1995).

\subsubsection{Correlation Analysis}

Correlation analysis is performed to determine the direction and strength of correlations between scales that have proved uni-dimensional by confirmatory factor analysis. The ab- 
sence of 1.0 in the confidence interval for the correlation coefficient of two constructs is an indication of a positive correlation (Hair et al. 1995). The coefficients of correlation obtained from the final confirmatory factor analysis are given in Table 6.

Table 6. Correlation Matrix Analysis

\begin{tabular}{|c|c|c|c|c|c|c|c|c|c|c|}
\hline $\begin{array}{l}\text { Pearson's coeffi- } \\
\text { cient of correlation }\end{array}$ & EOU & CST & USE & UFT & SVC & SCI & ECO & SBK & CRK & SAT \\
\hline \multirow{2}{*}{ EOU } & 1 & $.277^{\star}$ & $.291^{\star}$ & $.306^{*}$ & $.449^{*}$ & $.381^{\star}$ & $.172^{\star}$ & $.214^{\star}$ & $.119^{*}$ & $.158^{\star}$ \\
\hline & & $(.000)$ & $(.000)$ & $(.000)$ & $(.000)$ & $(.000)$ & $(.016)$ & $(.003)$ & $(.005)$ & $(.026)$ \\
\hline \multirow{2}{*}{ CST } & $.277^{\star}$ & 1 & $.533^{*}$ & $.289^{*}$ & $.306^{*}$ & $.341^{*}$ & $.354^{*}$ & $.119^{*}$ & $.406^{*}$ & $.431^{* *}$ \\
\hline & $(.000)$ & & $(.000)$ & $(.000)$ & $(.000)$ & $(.000)$ & $(.000)$ & $(.095)$ & $(.000)$ & $(.000)$ \\
\hline \multirow[t]{2}{*}{ USE } & $.291^{\star}$ & $.533^{\star}$ & 1 & $.330^{\star}$ & $.325^{\star}$ & $.320^{\star}$ & $.302^{\star}$ & $.137^{\star}$ & $.333^{\star}$ & $.304^{\star *}$ \\
\hline & $(.000)$ & $(.000)$ & & $(.000)$ & $(.000)$ & $(.000)$ & $(.000)$ & $(.008)$ & $(.000)$ & $(.000)$ \\
\hline \multirow[t]{2}{*}{ NET } & $.308^{\star}$ & $.239^{*}$ & $.330^{\star}$ & 1 & $.270^{\star}$ & $.413^{*}$ & .118 & $.243^{\star}$ & $.355^{\star}$ & .129 \\
\hline & $(.000)$ & $(.000)$ & $(.000)$ & & $(.000)$ & $(.000)$ & $(.099)$ & $(.001)$ & $(.000)$ & $(.071)$ \\
\hline \multirow[t]{2}{*}{ SVC } & $.449^{*}$ & $.306^{*}$ & $.325^{\star}$ & $.270^{*}$ & 1 & $.445^{\star}$ & $.227^{\star}$ & $.423^{*}$ & $.364^{\star}$ & $.291^{\star *}$ \\
\hline & $(.000)$ & $(.000)$ & $(.000)$ & $(.000)$ & & $(.000)$ & $(.001)$ & $(.000)$ & $(.000)$ & $(.000)$ \\
\hline \multirow[t]{2}{*}{ SCL } & $.381^{*}$ & $.341^{\star}$ & $.320^{*}$ & $.413^{\star}$ & $.445^{\star}$ & 1 & $.162^{\star}$ & $.255^{\star}$ & $.331^{\star}$ & $.267^{\star *}$ \\
\hline & $(.000)$ & $(.000)$ & $(.000)$ & $(.000)$ & $(.000)$ & & $(.023)$ & $(.000)$ & $(.000)$ & $(.000)$ \\
\hline \multirow[t]{2}{*}{ ECO } & $.172^{\star}$ & $.354^{\star}$ & $.302^{\star}$ & .118 & $.227^{\star}$ & $.162^{\star}$ & 1 & .138 & $.453^{\star}$ & $.430^{\star *}$ \\
\hline & $(.016)$ & $(.000)$ & $(.000)$ & $(.099)$ & $(.001)$ & $(.023)$ & & $(.054)$ & $(.000)$ & $(.000)$ \\
\hline \multirow[t]{2}{*}{ SAK } & $.214^{*}$ & .119 & $.137^{\star}$ & $.213^{*}$ & $.423^{\star}$ & $.255^{\star}$ & .138 & 1 & $.225^{\star}$ & .106 \\
\hline & $(.003)$ & $(.095)$ & $(.006)$ & $(.001)$ & $(.000)$ & $(.000)$ & $(.054)$ & & $(.001)$ & $(.132)$ \\
\hline \multirow[t]{2}{*}{ CRK } & $.119^{*}$ & $.405^{\star}$ & $.388^{\star}$ & $.355^{\star}$ & $.364^{\star}$ & $.331^{\star}$ & $.453^{*}$ & $.225^{\star}$ & 1 & $.295^{\star *}$ \\
\hline & $(.005)$ & $(.000)$ & $(.000)$ & $(.000)$ & $(.000)$ & $(.000)$ & $(.000)$ & $(.001)$ & & $(.000)$ \\
\hline \multirow[t]{2}{*}{ SAT } & $.158^{\star}$ & $.431^{\star}$ & $.304^{*}$ & $.129^{*}$ & $.291^{*}$ & $.257^{\star}$ & $.430^{*}$ & .106 & $.295^{\star}$ & 1 \\
\hline & $(.025)$ & $(.000)$ & $(.000)$ & $(.077)$ & $(.000)$ & $(.000)$ & $(.000)$ & $(.132)$ & $(.000)$ & \\
\hline
\end{tabular}

\subsection{Research Model and Hypothesis Testing}

The estimation of the research model proposed in this study resulted in the chi-square value of 7.098, p-value of 0.129 and a GFI of 0.989 , suggesting a good model fit. The results of the test where the fit indices were: $\mathrm{AGFI}=891$, RMR $=0.040, \mathrm{NFI}=937$ are as shown in Fig. 5. The path analysis performed on the structural model revealed that the average path score, excluding the paths between social benefits and satisfaction, between perceived risks (service risk and cost risk) and satisfaction, and between cost risk and consumer accept- 


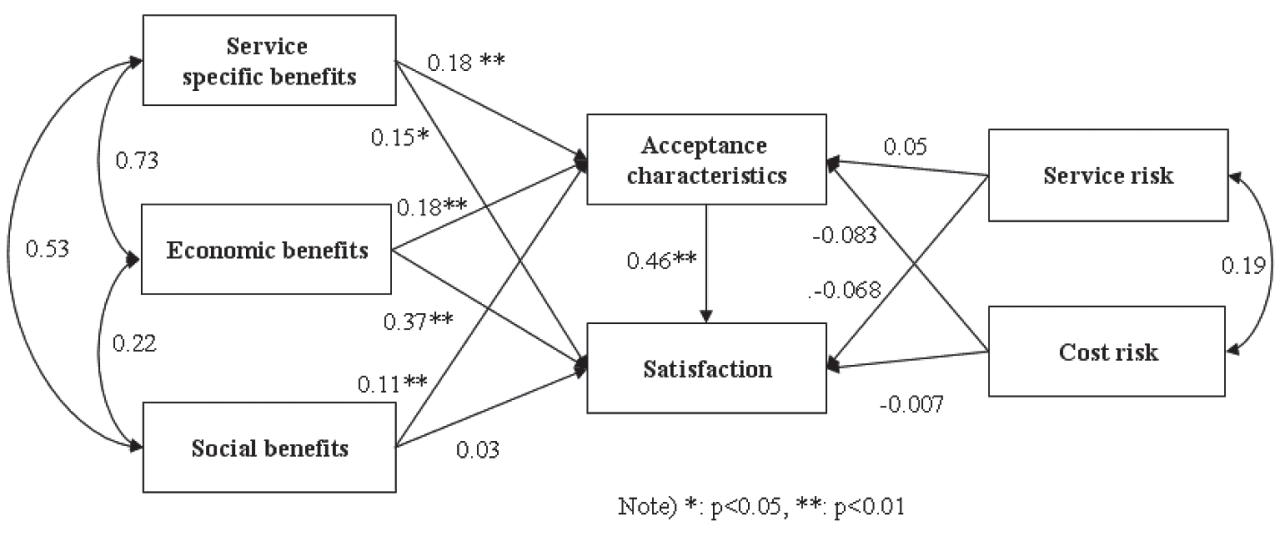

Fig. 5. Path Analysis of the Research Model

ance characteristics, had a positive value. The path analysis, further, revealed that the three benefits - service-specific benefits, economic benefits and social benefits - had an influence on consumer acceptance characteristics.

The results of the hypothesis testing are summarized in Table 7. As service-specific benefits, social benefits and economic benefits proved to have a positive influence on the consumer acceptance of mobile services and the satisfaction with mobile services, all three hypotheses related to perceived benefits [H 1-1, H 1-2 \& H 1-3] were accepted. As for [H 2-1], only a portion of the hypothesized content possessed explanatory power; service risk had a positive influence on the acceptance of mobile services, but had a negative influence on satisfaction. [H 2-2] was accepted in its entirety, as cost risk had a negative influence on both acceptance behavior and satisfaction. Finally, [H3] was also accepted, as the consumer acceptance of mobile services proved to have a positive influence on the level of satisfaction.

An additional analysis found that these variables influencing consumers' acceptance behavior with mobile services also indirectly influenced each other. Perceived benefits such as service-specific benefits, economic benefits and social benefits, in particular, influenced each other in a positive fashion. Meanwhile, perceived risks such as service risk and cost risk influenced each other in a negative manner, suggesting that cost risk has a sizeable influence on service risk. This result can be understood as an indication that consumers' avoidance of cost risk potentially reinforces their risk aversion at the level of service.

\section{Conclusion}

This study was an empirical investigation of consumers' usage behavior with regard to mobile telecommunications services. The test of the research model constructed to explain factors influencing consumers' acceptance indicated that expected benefits and risks of a new mobile service were the most important determinants of acceptance behavior. This would suggest that consumers' wariness of using mobile services stem to a large degree from the tendency of risk avoidance. The importance of expected benefits may also explain why consumers tend 
Table 7. Results of Hypothesis Testing and Analysis of Acceptance Influencing Factors

\begin{tabular}{|c|c|c|c|c|}
\hline & \multirow{2}{*}{ Hypotheses } & \multicolumn{3}{|c|}{ Test Results; Path Coefficients } \\
\hline & & Accept & & reject \\
\hline \multirow{2}{*}{$\begin{array}{l}\mathrm{H} \\
1-1\end{array}$} & \multirow{2}{*}{$\begin{array}{l}\text { Service-specific benefits have a positive } \\
\text { influence on the acceptance of an m- } \\
\text { service and the degree of satisfaction felt } \\
\text { by consumers }\end{array}$} & $\begin{array}{l}\text { Service-specific benefits à Accep- } \\
\text { tance behavior }\end{array}$ & 0.18 & \multirow{2}{*}{ Accepted } \\
\hline & & $\begin{array}{l}\text { Service-specific benefits à Satis- } \\
\text { faction }\end{array}$ & 0.15 & \\
\hline \multirow{2}{*}{$\begin{array}{l}\mathrm{H} \\
1-2\end{array}$} & \multirow{2}{*}{$\begin{array}{l}\text { Social benefits have a positive influence } \\
\text { on the acceptance of an m-service and the } \\
\text { degree of satisfaction felt by consumers }\end{array}$} & $\begin{array}{l}\text { Social benefits à Acceptance be- } \\
\text { havior }\end{array}$ & 0.18 & \multirow[t]{2}{*}{ Accepted } \\
\hline & & Social benefits à Satisfaction & 0.03 & \\
\hline \multirow{2}{*}{$\begin{array}{l}\mathrm{H} \\
1-3\end{array}$} & \multirow{2}{*}{$\begin{array}{l}\text { Economic benefits have a positive influ- } \\
\text { ence on the acceptance of an m-service } \\
\text { and the degree of satisfaction felt by } \\
\text { consumers }\end{array}$} & $\begin{array}{l}\text { Economic benefits à Acceptance } \\
\text { behavior }\end{array}$ & 0.11 & \multirow{2}{*}{ Accepted } \\
\hline & & Economic benefits à Satisfaction & 0.37 & \\
\hline \multirow{2}{*}{$\begin{array}{l}\mathrm{H} \\
2-1\end{array}$} & \multirow{2}{*}{$\begin{array}{l}\text { The service risk associated with an m- } \\
\text { service has a negative influence on its } \\
\text { acceptance and the degree of satisfaction } \\
\text { felt by consumers }\end{array}$} & Service riskà Acceptance behavior & 0.05 & \multirow[b]{2}{*}{ Rejected } \\
\hline & & Service risk à Satisfaction & -0.07 & \\
\hline \multirow[b]{2}{*}{$\begin{array}{l}\mathrm{H} \\
2-2\end{array}$} & \multirow{2}{*}{$\begin{array}{l}\text { The cost risk associated with an } \mathrm{m} \text {-service } \\
\text { has a negative influence on its acceptance } \\
\text { and the degree of satisfaction felt by } \\
\text { consumers }\end{array}$} & Cost risk à Acceptance behavior & -0.08 & \multirow[b]{2}{*}{ Accepted } \\
\hline & & Cost risk à Satisfaction & -0.01 & \\
\hline $\mathrm{H} 3$ & $\begin{array}{l}\text { The characteristics of consumer ac- } \\
\text { ceptance of } m \text {-services have a positive } \\
\text { influence on satisfaction }\end{array}$ & $\begin{array}{l}\text { Acceptance behavior à Accep- } \\
\text { tance behavior }\end{array}$ & 0.46 & Accepted \\
\hline
\end{tabular}

to use only some of the many seemingly exciting new mobile services made available thanks to the technological progress; a selectiveness hardly affected by the level of knowledge of information technology and information skills. The implication of this behavioral tendency for service providers is that they need to adopt a marketing strategy which is centered on reducing perceived risk factors associated with using mobile services. Also, given the important role of perceived benefits in consumers' purchase decision, service providers must look to develop services that are more accessible and diversify their content offerings to better meet the growing information demand among consumers.

One limitation of this study is that we did not consider differences that may exist between individual mobile carriers, in terms of service characteristics, as its focus was to understand factors influencing mobile services' acceptance behavior. Notwithstanding, as our estimation of consumers' usage behavior with mobile services was based on data from the age and social groups that are the most active users of wireless internet, we expect our results to be useful for service providers in developing target group-specific marketing strategies. Future research can overcome the limitations of the present research and provide a more comprehensive understanding of consumers' acceptance mechanism by considering also factors influencing the adoption of mobile services among users of GSM-type mobile telephony, and not just among users of CDMA telephony, whose use is limited to Korea, Japan and parts of the US. 


\section{References}

Amberg, M.; Hirschmeier, M.; Wehrmann, J. 2003. The Compass Acceptance Model for the Analysis and Evaluation of Mobile Information Systems, International Journal for Mobile Communications (IJMC), Finland (Submitted).

Bauer, R. A. 1960. Consumer Behavior as Risk Taking, in Hancock, R. S. (Edt.). Dynamic Marketingfor a Changing World: Proceeding of the 43rd Conference of the American Marketing Association. Chicago, 390.

Benbasat, I.; Dexter, A. S. 1992. An investigation of the effectiveness of color and graphical presentation under varying time constraints, MIS Quarterly March: 59-84.

Bettman, J. R. 1973. Perceived Risk and Its Components: A Model and Empirical Test, Journal of Marketing Research 10: 184. doi:10.2307/3149824

Borchert, J.; Goos, P.; Hagenhoff, S. 2004. Innovations-und Technologie management: Eine Bestandsaufnahme [Innovation and technology management: an overview], in Schumann, M. (Ed.). Arbeitsbericht 4/2003, Institut für Wirtschafts informatik [Institute of Economic computer science], Georg-AugustUniversität, Götingen.

Bullinger, H.-J.; Schreiner, P. 2003. Service Engineering: Ein Rahmenkonzept für die systematische Entwicklung von Dienstleistungen [A conceptual framework for the systematic development of services], in Bullinger, H.-J.; Scheer, A.-W. Service Engineering-Entwicklung und Gestaltung innovativer Dienstleistungen, 51-82.

Buse, S. 2002. Der mobile Erfolg-Ergebnisse einer empirischen Untersuchung in ausgewalten Branchen, in Keuper, F. (Edt.). Electronic Business and Mobile Business. Wiesbaden, 92.

Campbell, D. T.; Fiske, D. W. 1959. Convergent and Discriminant Validation by the Multitrait-Multimethod Matrix, Psychological Bulletin 56(2 March): 81-105.

Cox, D. F. 1967. Risk Handling in Consumer Behavior-an Intensive Study of Two Cases, in Cox, D. F. (Edt.). Risk Taking and Information Handling in Consumer Behavior, Boston, 37.

Cunningham, S. M. 1967. The Major Dimensions of Perceived Risk, in Cox, D. F. (Edt.). Risk Taking and Information Handling in Consumer Behavior, Boston, 83.

Davis, F. D. 1989. Perceived Usefulness, Perceived Ease of Use, and User Acceptance of Information Technology, MIS Quarterly 13(3): 319-340. doi:10.2307/249008

Davis, F. D.; Bagozzi, R. P.; Warshaw, P. R. 1989. User acceptance of computer technology: A comparison of two theoretical models, Management Science 35: 982.

Dishaw, M. T.; Strong, D. M. 1998. Assessing Software Maintenance Tool Utilization Using TaskTechnology Fit and Fitness-for Use Models, Journal of Software Maintenance: Research and Practice 10(3): 151-179. doi:10.1002/(SICI)1096-908X(199805/06)10:3<151::AID-SMR165>3.0.CO;2-\#

Döring, N. 2002. Kommunikative Funktionen von Kurzmitteilungen (SMS) [Communocative fuction of short message], Zeitschrift für Medienpsychologie [Journal of Media Psychology] 14(3): 118-128.

Fishbein, M.; Ajzen, I. 1975. Belief, Attitude, Intention and Behavior: An Introduction to Theory and Research. Anderson-Wesley Publishing Company.

Gefen, D.; Staub, D. 2000. The Relative Importance of Perceived Ease of Use in IS Adoption: A Study of eCommerce Adoption, Journal of the Association for Information Systems 8.

Gerpott, T. J. 1999. Strategisches Technologie- und Innovationsmanagement: eine konzentrierte Einfürung [Concentrate introduction of measures]. Stuttgart, 55.

Goodhue, D. L.; Thompson, R. L. 1995. Task-Technology Fit and Individual Performance, MIS Quarterly 19(2): 213-236.

Hair, R. E. Anderson, R. L. Tatham, and W. C. Black, 1992. Multivariate Data Analysis With Readings, 3rd Ed. New York: Macmillan Publishing Company

Harms, A. 2002. Adoption technologiebasierter Self-Service-Innovationen: Analyse der Wirkungsmechanismen, in Entscheidungsprozess der Konsumenten. Wiesbaden. 
Hoffman, D. L.; Novak, T. P. 1996. Marketing in Hypermedia Computer-Mediated Environments; Conceptual Foundations, Journal of Marketing 60(July): 50-68. doi:10.2307/1251841

Kim, K. S. 2001. Structural Equation Modeling with AMOS. Seoul: Goryeo Jeongbo Saneop.

Lederer, A. I.; Maupin, D. J.; Sena, M. P.; Zhuang, Y. 2000. The Technology Acceptance Model and the world wide Web, Decision Support Systems 29(3): 269-282. doi:10.1016/S0167-9236(00)00076-2

Lehner, F. 2003. Mobile und drahtlose Informationssysteme. Technologien, Anwendungen, Märkte [Mobile and wireless information systems. Technologies, applications, markets], Heidelberg, Germany.

Neudorfer, R. 2004. Critical Success Factors for the Management of innovative Mobile Business Models, in Merkur Day 2004: 6th Undergraduate and Graduate Students eConference.

Reichwald, R. 1982. Neue Systeme der Börtechnik und Büroarbeitsgestaltung-Problemzusammenhänge [New systems of hearing technology and office-work design problem relationships], in Reichwald, R. (Hrsg.). Neue Systeme der Bürotechnik: Beiträge zur Bürogestaltung aus Anwendersicht. Berlin.

Rogers, E. M. 1995. Diffusion of Innovations. 3rd edition. New York/London .

Schmalen, H.; Pechtl, H. 1996. Die Rolle der Innovationseigenschaften als Determinanten im Adoptionsverhalten [The role of innovation characteristics as determinants of adoption behavior], Zf bf 48: 814-822.

Silberer, G.; Magerhans, A.; Wohlfahrt, J. 2002. Kundenzufriedenheit und Kun denbindung im Mobile Commerce [Customer satisfaction and customer retention in mobile commerce], in Silberer, G.; Wohlfahrt, J.; Wilhelm, T. (Eds.). Mobile Commerce. Grundlagen, Geschärtsmodelle, Erfolgsfaktoren. Wiesbaden, 309-324.

Turowski, K.; Pousttch, K. 2004. Mobile Commerce. Grundlagen und Techniken [Principles and Techniques]. Springer Verlag, Berlin.

Villanen, J., Modée, K., Koivula, J., Pousttchi, K. \& Gumpp, A., 2004. Mobile Enterprise in Germany State-of-the-art, Expectations and Perspectives for Mobile Business Processes in Small and Medium-sized Enterprises on the German Market. Joint Study by the Finnish Foreign Trade Association (FINPRO) and the University of Augsburg (Chair of Business Informatics and Systems Engineering), Munich, Germany.

Weiber, R. 1992. Diffusion von Telekommunikation: Problem der kritischen Masse [Diffusion of telecommunications: the critical mass problem]. Wiesbaden.

Weiber, R. 1994. Ausgewählte Theorieansätze zur Erklärung des Nachfrage verhaltens bei technologischen Innovationen [Selected theories to explain the behavior of demand for technological innovations], in Pohl, A. (Hrsg.). Arbeitspapier zur Marketingtheorie 4, Trier, 110-118.

\title{
MOBILIOJO RYŠIO PASLAUGUৃ NAUDOJIMAS KORĖJOJE: EMPIRINIS TYRIMAS APIE INOVATYVIŲ TECHNOLOGIJŲ PRIPAŽINIMĄ TARP VARTOTOJŲ
}

\author{
Y. W. Sawng, S. H. Kim, J. Lee, Y. S. Oh
}

Santrauka. Pastaraisiais metais mobiliojo ryšio paslaugų rinka labai išsiplètè ir nepaprastai greitai susisiejo su giminingomis technologijomis, tačiau vartotojų požiüris ị šias paslaugas iki šiol nesulaukè pakankamai mokslininkų dèmesio. Tyrimų šioje srityje atlikta nedaug. Pagrindinis šio straipsnio tikslas - išsiaiškinti vartotojų naudojimosi mobiliojo ryšio paslaugomis elgesio ypatumus ir būsimos plètros galimybes šioje srityje. Šiuo tyrimu siekiama nustatyti ịvairių veiksnių įtaką mobiliojo ryšio paslaugos gavejams. Sukurtas vartotojų elgesi prognozuojantis modelis. Šis tyrimas yra glaudžiai susijęs su mobiliojo ryšio paslaugų rinkodara, darančia ịtaką vartotojų elgsenai ir techniniams paslaugų aspektams. Veiksniai, darantys ịtaką mobiliojo ryšio vartotojų elgsenai, tiriami empiriškai realiojo pasaulio kontekste. Laukiami šios studijos rezultatai yra šie: pirma, bus galima prognozuoti vartotojų naudojimosi mobiliojo ryšio paslaugomis elgsenos ypatybes; antra, mobiliojo ryšio tiekẻjai sužinos apie paslaugos teikimo techninės ir funkcinės pusės svarbą, supras vartotojų poreikių įtaką mobiliojo ryšio paslaugų rinkodarai. 
Reikšminiai žodžiai: mobiliojo ryšio paslauga, vartotojų patogumas, vartotojų prièmimas, vartotojų ketinimai.

Yeong-Wha SAWNG is a senior researcher of the Service Strategy Research team at the Electronics and Telecommunications Research Institute (ETRI), Korea. He received an MIM in Management from Whitworth University, USA and a PhD in Technology Management from Hanyang University Seoul, Korea in 1995 and 2006, respectively. He joined ETRI in 2000, and has been working in the areas of digital convergence, IT policy, mobile application, technology management and business strategy. His research interests also include high-tech. marketing, technology management strategy, e/m-Biz model and consumer behaviour. He has been published in several international and Korean journals.

Seung-Ho KIM is the vice president of Korea Institute of Industrial Evaluation, which does consulting and designing for firm organisation. He received an MS in Business Administration at Seoul National University, Korea in 1998. His research interests are in the fields of technology innovation, work group design, strategic management of technology and R\&D project management.

Jungmann LEE obtained his PhD in Economics from the City University of New York. His research has focused on the areas of technology policy, R\&D management, and the economics of technology innovation at the Electronics and Telecommunications Research Institute. He has also served as an advisor for various projects (mid-long term IT technology policy, the technology roadmap of information and telecommunications and IT HRD Policy) of the Ministry of Information and Communication, Korea. He is an assistant professor at the Department of Digital Business at Hoseo University.

Young Sam OH received his BA from the HanKook University of Foreign Studies and MBA from Inha University in 1992 and 1995, respectively. For over 9 years, he has taught high-tech. marketing as an adjunct professor at Woosong University. He is currently a Ph. D candidate of Inha University. His research is focused on IT and Service Management. 